\title{
29. BACTERIAL PROFILES IN HYDROTHERMALLY ACTIVE DEEP SEDIMENT LAYERS FROM MIDDLE VALLEY (NE PACIFIC), SITES 857 AND 858 ${ }^{1}$
}

\author{
B.A. Cragg ${ }^{2}$ and R.J. Parkes ${ }^{2}$
}

\begin{abstract}
Sediment samples ( $2 \mathrm{~cm}^{3}$ each) were obtained from Ocean Drilling Program Leg 139 Sites 857 and 858 in the Middle Valley of the northern Juan de Fuca Ridge for direct microscopic determination of bacterial depth distributions in a region influenced by hydrothermal activity. Site 857 (Holes $857 \mathrm{~A}$ and $857 \mathrm{~B}$ ) was $1.6 \mathrm{~km}$ away from Site 858 , a hydrothermal venting area, but had a similar regional structural setting and thus provided a reference site. Hydrothermal samples were obtained from four holes drilled in a transect into the active vent field at Site 858. Temperatures increased from Hole 858A to 858C to 858B to 858D with approximate temperatures at 10 meters below seafloor (mbsf) of $20^{\circ}, 33^{\circ}, 100^{\circ}$, and $105^{\circ} \mathrm{C}$, respectively, compared with approximately $8^{\circ} \mathrm{C}$ at 10 mbsf in Holes 857A and B. At Site 857 substantial bacteria populations, including dividing cells, were present in all samples (deepest sample $107.5 \mathrm{mbsf}$ ) and there were no significant differences between data from the two holes approximately $10 \mathrm{~m}$ apart. This implies that there is considerable microbial homogeneity between these spatially close areas of the seafloor, and thus the data were combined. Bacterial numbers were highest, $1.73 \times 10^{7} \mathrm{cells} / \mathrm{cm}^{3}$, in the near-surface samples at $1.51 \mathrm{mbsf}$ and decreased linearly with increasing depth to $1.07 \times 10^{6}$ cells $/ \mathrm{cm}^{3}$ at $107.5 \mathrm{mbsf}$, a 16 -fold decrease. This distribution is similar to those at other sites previously studied, despite the low organic carbon concentration $(0.56 \%)$ compared to these other sites. In contrast, bacterial distributions at the four holes of the hydrothermal upwelling site differed significantly and could not be combined. Although near-surface bacterial populations were similar to those at the reference site at $1.51 \mathrm{mbsf}, 2.90 \times 10^{6} \mathrm{cells} / \mathrm{cm}^{3}$ to $1.58 \times 10^{7}$ cells $/ \mathrm{cm}^{3}$, bacterial populations decreased rapidly with depth; the deepest sample with significant populations was $64 \mathrm{mbsf}$. The higher temperature gradients at this site may limit the bacterial depth distribution to a much greater extent than at Site 857, although both sites have a similar low organic carbon content. Average total organic carbon in the top $5 \mathrm{~m}$ was $0.56 \%$ at Site 857 and $0.48 \%$ at Site 858 . However, due to the steep thermal gradients encountered at Site $858\left(1.7\right.$ to $\left.11^{\circ} \mathrm{C} / \mathrm{m}\right)$, bacteria even at shallow depths appear to be adapted to high temperatures and hence may be considered thermophilic. Depth profiles of bacterial populations at the vent sites are related to chlorinity changes, which reflect the influence of vent fluid. At the two "hot" holes (858B and 858D) which were influenced by near-surface lateral fluid flow, there was a significant $(P<0.001)$ subsurface peak in the bacterial population associated with increases in chlorinity and a temperature increase to $169^{\circ} \mathrm{C}$. The presence of these bacterial populations was difficult to attribute to contamination during drilling from above, or cooling artifacts, and thus may represent uniquely high-temperature-adapted (hyperthermophilic) bacteria.
\end{abstract}

\section{INTRODUCTION}

Previous Ocean Drilling Program (ODP) research on marine sediments (Cragg et al., 1990; Parkes et al., 1990; Cragg et al., 1992; Parkes et al., in press; Cragg, in press) has confirmed the extensive indirect geochemical evidence that microbial activity is continuous to considerable depths within sediments, including chemical changes in pore water, gas production, modification of organic complexes such as kerogen, concretion formation, and isotopic evidence. In most sediments, temperature is unlikely to limit bacterial activity until several $\mathrm{km}$ below the seafloor, as bacteria can grow in excess of $110^{\circ} \mathrm{C}$ (Huber et al., 1989; Pledger and Baross, 1991; Stetter et al., in press) and the thermal gradient of the Earth's crust is approximately $10^{\circ}-40^{\circ} \mathrm{C} / \mathrm{km}$. However, in areas of geothermal activity, such as at hydrothermal vents, temperatures in excess of $350^{\circ} \mathrm{C}$ can be reached, exceeding the growth temperature of even the most thermophilic bacteria ${ }^{3}$ hence limiting bacterial distributions (Karl et al., 1988; Stetter et al., 1990, in press).

Although the chimneys, vent fluids, surrounding water, and shallow sediments of hydrothermal systems have been studied and several extreme thermophiles $\left(65^{\circ}-95^{\circ} \mathrm{C}\right)$ and hyperthermophiles ${ }^{3}$ isolated (Jannasch and Mottl, 1985; Fiala and Stetter, 1986; Jannasch et al., 1988; Karl et al., 1988; Huber et al., 1989, 1990; Stetter et al., 1990, in

\footnotetext{
${ }^{1}$ Mottl, M.J., Davis, E.E., Fisher, A.T., and Slack, J.F. (Eds.), 1994. Proc. ODP. Sci. Results, 139: College Station, TX (Ocean Drilling Program).

${ }_{3}^{2}$ Dept. of Geology, University of Bristol, Bristol, BS8 1RJ, United Kingdom.

3 "Thermophile" is defined as bacteria able to grow above $55^{\circ} \mathrm{C}$ and "hyperthermophile" is defined as bacteria with a growth optimum above $80^{\circ} \mathrm{C}$.
}

press), including samples from the Juan de Fuca Ridge (Pledger and Baross, 1989, 1991; Reysenbach and Deming, 1991), deeper sediment layers have not been studied. The sediment-covered spreading center of Middle Valley on the Juan de Fuca Ridge, sampled during Leg 139, proved an ideal site for investigating the bacterial distributions in deep sediments within submarine hydrothermal systems.

\section{MATERIALS AND METHODS Site Descriptions}

Sites 857 and 858 are in Middle Valley on the northern Juan de Fuca Ridge off the northwest coast of North America (Fig. 1A). Site 857 is located approximately $1.6 \mathrm{~km}$ from Site 858 , which is over an active hydrothermal vent field. Site 857 has a regional structural setting similar to Site 858 and hence provides a reference for the hydrothermal upwelling site. Sediment cover is thick and locally continuous with a relatively high heat flow of $0.71 \mathrm{~W} / \mathrm{m}^{2}$. Hole $857 \mathrm{~B}$ was drilled to better define the upper $30 \mathrm{~m}$ of the sediment and was approximately $10 \mathrm{~m}$ laterally displaced from Hole 857A (Davis, Mottl, Fisher, et al., 1992). At Site 858 , heat flow ranges from $1 \mathrm{~W} / \mathrm{m}^{2}$ through the surrounding seafloor to over $20 \mathrm{~W} / \mathrm{m}^{2}$ in the field itself. Four holes were drilled in a transect into the active vents (Fig. 1B). Hole 858A was drilled approximately $150 \mathrm{~m}$ west of the nearest currently active vent and had a thermal gradient of $1.7^{\circ} \mathrm{C} / \mathrm{m}$. Hole $858 \mathrm{C}$ was located within the distal part of the vent field area, $70 \mathrm{~m}$ west of the nearest known vent, and had a temperature gradient of $3^{\circ} \mathrm{C} / \mathrm{m}$. Hole $858 \mathrm{~B}$ was located only a few meters from a $276^{\circ} \mathrm{C}$ thermal vent, and Hole $858 \mathrm{D}$ was at the center of the vent field area, about $70 \mathrm{~m}$ northeast of the nearest active vent at Hole 858B (Davis, Mottl, Fisher, et al., 1992). 


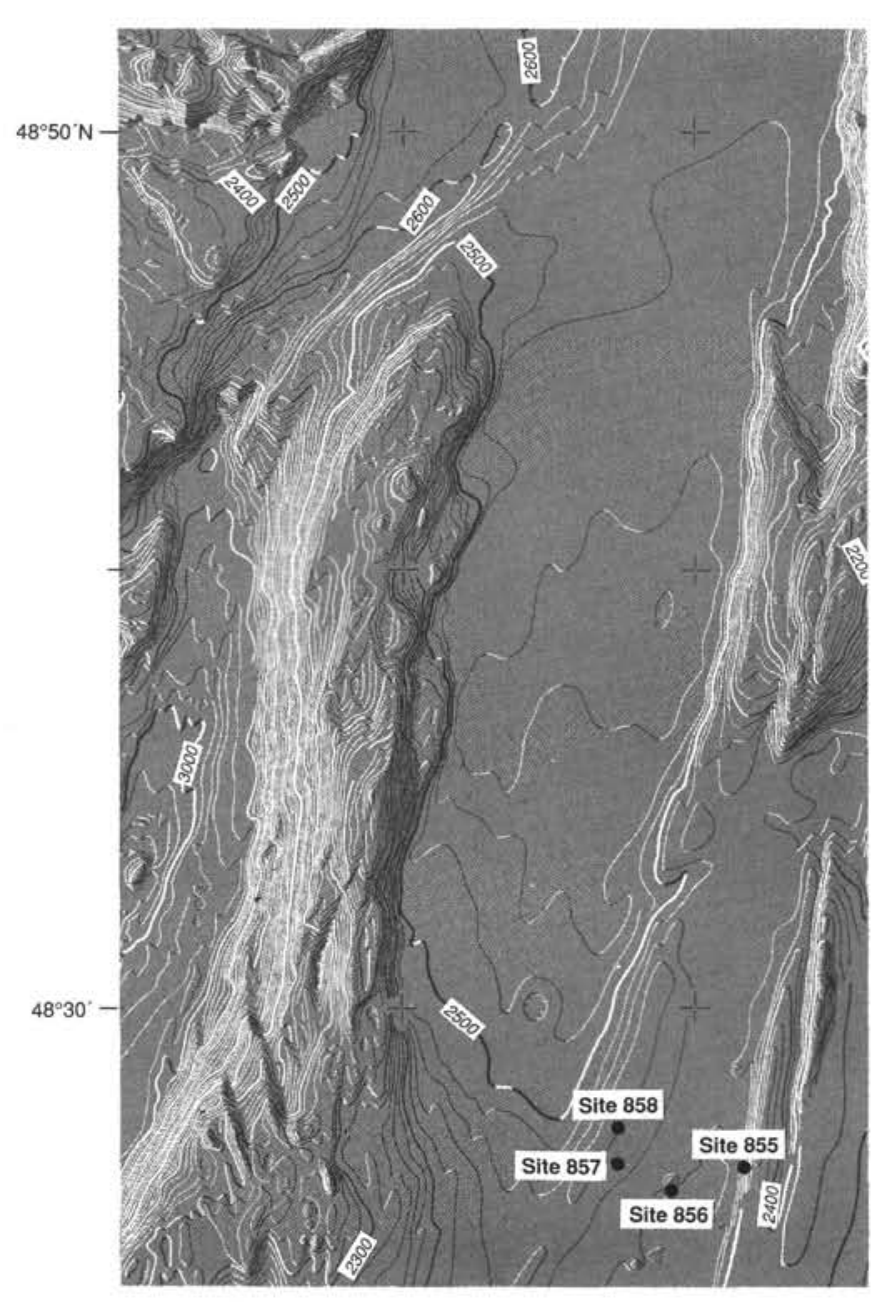

Figure 1. Map of the sampling area for Leg 139. A. Bathymetry of the northern Juan de Fuca Ridge, shown as contours drawn at 20-m intervals and "illuminated" from the west. Site locations for Leg 139 are indicated. B. Geologic map of the Site 858 vent field, showing the location of Holes $858 \mathrm{~A}-\mathrm{G}$, known hydrothermal mounds and vents, and the temperatures of discharging water (J. Franklin, pers. comm., 1991). Both diagrams from Davis, Mottl, Fisher, et al. (1992).

\section{Shipboard Handling}

A total of $772-\mathrm{cm}^{3}$ sediment samples were taken from six holes over two sites (Table 1). Samples were removed from the cut ends of $1.5-\mathrm{m}$ core sections as they were cut on the catwalk. A thin layer of sediment was removed from the cut surface with a sterile scalpel to expose an uncontaminated surface and a sterile (autoclaved) $5-\mathrm{mL}$ plastic syringe, from which the luer end had been removed, was used to take a $2-\mathrm{cm}^{3}$ minicore. This sample was divided into two. The initial $1 \mathrm{~cm}^{3}$ was ejected directly into a tared serum vial containing $9 \mathrm{~mL}$ of filter sterilized $(0.2-\mu \mathrm{m}) 4 \%$ formaldehyde in artificial seawater, crimp sealed, and shaken vigorously to disperse the sediment plug. The second $1 \mathrm{~cm}^{3}$ was put into a tared clean sample vial for wet/dry weight and organic matter determination.

\section{Laboratory Handling}

\section{Direct Microscopic Observation}

Acridine orange staining and microscopic observations were based on the general recommendations of Fry (1988). For all samples, $8 \mathrm{~mL}$ of formaldehyde-preserved subsample were stained with acridine orange ( $50 \mathrm{~mL}$ of $1 \mathrm{~g} / \mathrm{L}$ solution) in $10 \mathrm{~mL}$ of filter sterilized $(0.1-\mu \mathrm{m}$
B

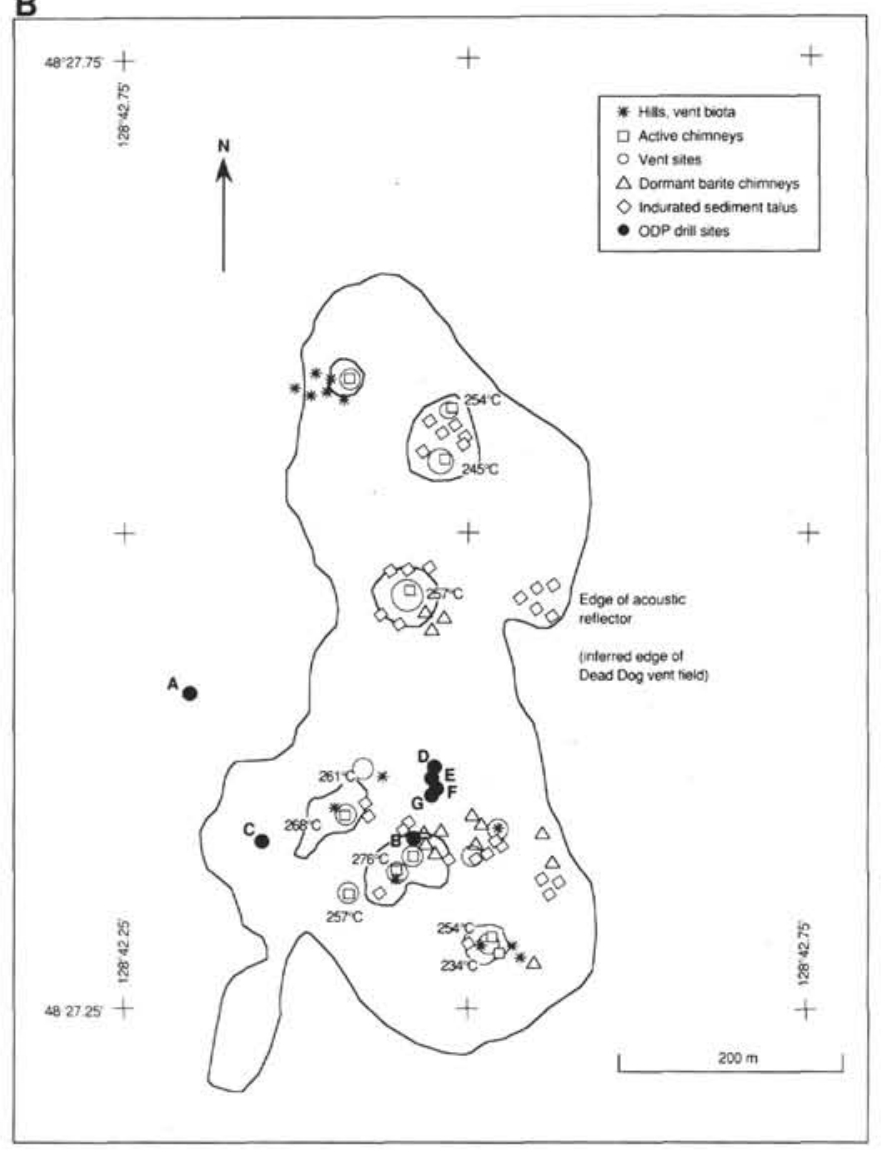

Figure 1 (continued).

Table 1. List of Site 857 and Site 858 samples provided for direct bacterial counts.

\begin{tabular}{|c|c|c|c|c|}
\hline Site/Hole & Position & $\begin{array}{c}\text { Water } \\
\text { depth (m) }\end{array}$ & $\begin{array}{l}\text { Maximum } \\
\text { sample } \\
\text { depth (mbsf) }\end{array}$ & $\begin{array}{l}\text { Number } \\
\text { of samples }\end{array}$ \\
\hline $857 \mathrm{~A}$ & $\begin{array}{l}48^{\circ} 26.496^{\prime} \mathrm{N} \\
128^{\circ} 42.804^{\prime} \mathrm{W}\end{array}$ & 2420.2 & 107.51 & 26 \\
\hline $857 \mathrm{~B}$ & $\begin{array}{l}48^{\circ} 26.490^{\prime} \mathrm{N} \\
128^{\circ} 43.804^{\prime} \mathrm{W}\end{array}$ & 2418.3 & 30.01 & 7 \\
\hline $858 \mathrm{~A}$ & $\begin{array}{l}48^{\circ} 27.414^{\prime} \mathrm{N} \\
128^{\circ} 42.780^{\prime} \mathrm{W}\end{array}$ & 2409.1 & 66.99 & 17 \\
\hline $858 B$ & $\begin{array}{l}48^{\circ} 28.050^{\prime} \mathrm{N} \\
128^{\circ} 42.546^{\prime} \mathrm{W}\end{array}$ & 2409.3 & 16.71 & 5 \\
\hline $858 \mathrm{C}$ & $\begin{array}{l}48^{\circ} 27.336^{\prime} \mathrm{N} \\
128^{\circ} 42.660^{\prime} \mathrm{W}\end{array}$ & 2416.9 & 43.01 & 13 \\
\hline $858 \mathrm{D}$ & $\begin{array}{l}48^{\circ} 27.372^{\prime} \mathrm{N} \\
128^{\circ} 42.528^{\prime} \mathrm{W}\end{array}$ & 2415.1 & 27.31 & 9 \\
\hline
\end{tabular}

pore size) $2 \%$ formaldehyde for three minutes and then filtered through a polycarbonate $(0.2-\mu \mathrm{m}$ pore size) membrane (Appleton Woods, Birmingham, U.K.). The membrane was then rinsed with a further 10 $\mathrm{mL}$ of $2 \%$ filter sterilized formaldehyde and mounted in a minimum of paraffin oil under a coverslip.

The mounted membrane filters were viewed under incident illumination with a Zeiss Axioskop microscope fitted with a 50-W mercury vapor lamp, a wide-band interference filter set for blue excitation, a $100-\times$ (numerical aperture $=1.3$ ) Plan Neofluar objective lens, and $10-\times$ eyepieces. The large amount of loose debris in the samples determined the low sample volume $(8 \mu \mathrm{L})$ for counting and this reduced the sensitivity of counting. Two replicate filters were prepared from each sample to minimize count variance (Kirchman et al., 1982). 
Where replicate $\log _{10}$ counts differed by more than $0.5 \log$ units, a third replicate filter was prepared. A minimum of 200 fields of view were counted when a total of less than 20 cells was encountered during enumeration of a single membrane filter. Both the total number of bacteria and the numbers of dividing/divided cells were counted and the number of cells counted on particles was doubled to account for cells hidden from view (Goulder, 1977). Where zero bacterial cells were actually encountered in a sample, the count was given a nominal value of $1 \times 10^{4}$, which is below the smallest detectable count. Daily reagent and membrane filter blanks were counted and zero, or acceptably near to zero, cells were detected. Bacterial counts were calculated after subtraction of the appropriate blank.

\section{Porosity and Organic Matter}

Sediment wet/dry weight ratios and porosity were obtained by drying $1 \mathrm{~cm}^{3}$ of sediment to constant weight at $105^{\circ} \mathrm{C}$. Organic matter was estimated by heating dried sediment in a muffle furnace at $450^{\circ} \mathrm{C}$ to constant weight. After the sample had been destructively treated for this measurement, a small random error was detected in the balance, making the data unreliable. These data were therefore discarded, and the more limited shipboard data were used where necessary.

\section{RESULTS AND DISCUSSION}

\section{Site 857}

A paired sample t-test between approximately congruent data from Holes 857A and 857B showed no significant difference $(t=1.51, N$ $=6, P<0.2$ ). The data from both holes were therefore combined. Previous work on Leg 138, Site 851 had also shown no significant difference in both total and dividing cell counts obtained from similar depths in two adjacent holes. Together these two observations suggest an encouraging degree of precision in the method of direct counting between samples and indicates that spatially close areas of the seafloor are microbially homogeneous.

Numbers of bacterial cells counted were low, averaging 0.13 cells per field of view (fov) over all 33 samples. Kirchman et al. (1982) consider less than 25 cells/fov to increase data variance significantly. However, Fry (1988) considers 10 cells/fov to be acceptable, and variance can be substantially decreased by increasing the numbers of fields of view from the usual $7-10$ to at least 200 . A paired sample t-test between the total count replicates showed no significant difference $(t=1.15, N=30, P<0.2)$.

A "significance level" was constructed from the data by selecting all counts in which fewer than 20 cells in total were enumerated on a membrane and calculating the total count on the basis of only a single cell being encountered on that membrane. The mean, which represents the average detection limit of all low ( $<20$ cells/membrane) counts, and $95 \%$ confidence limit of these results was $2.16 \times 10^{5} \pm$ $1.17 \times 10^{4} \mathrm{cells} / \mathrm{cm}^{3}$. The "significance level" was set to the mean plus $95 \%$ confidence limit at $5.36 \log _{10}$ units (Fig. 2). Counts below this level are the result of extremely low occurrences of bacterial cells in larger numbers of fov (up to 350) and are hence real, although their accuracy is low.

Bacteria were present in all samples in both holes, with the deepest samples being taken at 107.5 mbsf. The highest count was $1.73 \times 10^{7}$ cells $/ \mathrm{cm}^{3}$ at $1.51 \mathrm{mbsf}$, decreasing to $1.07 \times 10^{6} \mathrm{cells} / \mathrm{cm}^{3}$ at 107.51 mbsf, a 16-fold decrease in numbers (Fig. 2). The lowest count was $8.15 \times 10^{5}$ cells $/ \mathrm{cm}^{3}$ at $86.41 \mathrm{mbsf}$, a 21 -fold decrease from nearsurface numbers. The presence of significant bacterial populations throughout the $107 \mathrm{~m}$ of sediment is in agreement with the geochemical data, indicating that chemical profiles at this site are generally controlled by bacterial degradation of organic matter within the top 100 mbsf (Davis, Mottl, Fisher, et al., 1992). Sulfate decreases over the upper $53 \mathrm{~m}$, coinciding with increases in alkalinity, phosphate, and ammonium. The bacterial population was therefore active, resulting in the presence of significant numbers of dividing cells (Fig. 2). The total

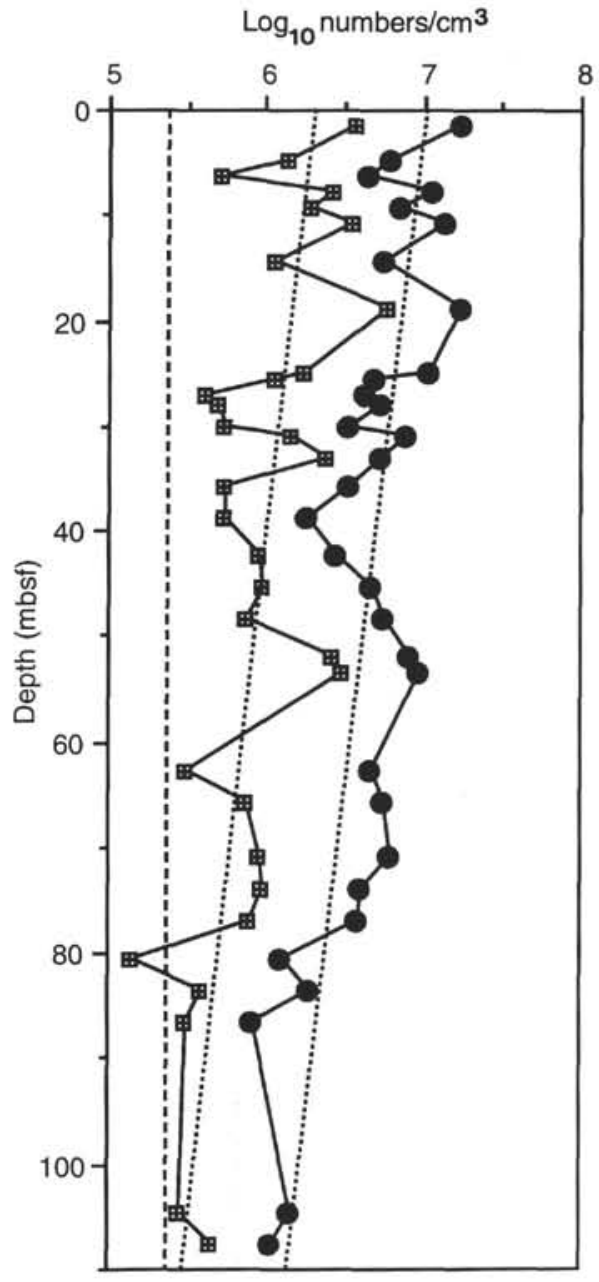

Figure 2. Depth distribution of total bacteria (solid circles) and dividing cells (open squares) using the Acridine Orange Direct Count (AODC) technique to 107.5 mbsf. Data from Holes 857A and 857B are combined. Vertical dashed line at 5.36 represents the calculated "significance level" for the presence of bacterial cells. The two slanted dashed lines are linear regression lines calculated as $\log _{10}$ cells $/ \mathrm{cm}^{3}=-0.0079 \times \mathrm{mbsf}+7.01$ and $\log _{10}$ cells $/ \mathrm{cm}^{3}=$ $-0.0076 \times \mathrm{mbsf}+6.30$ for total count and dividing cells, respectively.

count and dividing cell count were strongly correlated $(R=0.853, N$ $=33, P<0.002$ ). This close relationship has been observed at a number of other sites (Cragg et al., 1990, 1992; Cragg in press).

The depth profile for total bacteria was linear $\left(R^{2}=0.511\right)$ (Fig. 2 ). Regression analysis indicated scatter over the top $38 \mathrm{~m}$ of the profile, where bacterial degradation of organic carbon was concentrated, as reflected in a five-fold increase in alkalinity (Davis, Mottl, Fisher, et al., 1992). Total count and dividing cell count decreased linearly with depth at almost parallel rates (in $\log _{10}$ terms) of -0.0079 and $-0.0076 \log _{10}$ units $/ \mathrm{m}$, respectively.

\section{Site $\mathbf{8 5 8}$}

Of the 44 samples obtained from this site only 17 contained conclusive evidence of the presence of bacterial cells and, apart from one occurrence at $63.99 \mathrm{mbsf}$, all significant counts were encountered in sediments above $21 \mathrm{mbsf}$ (Fig. 3). The "significance level," which was calculated as described for Site 857 , was $1.90 \times 10^{5} \pm 5.8 \times 10^{4}$ cells $/ \mathrm{cm}^{3}$ (mean and $95 \%$ confidence limit, respectively) and was set to $5.29 \log _{10}$ units (Fig. 3).

The numbers of cells counted on the membranes was particularly low, averaging 0.047 cells/fov; nevertheless, as 13 of the 17 positive 


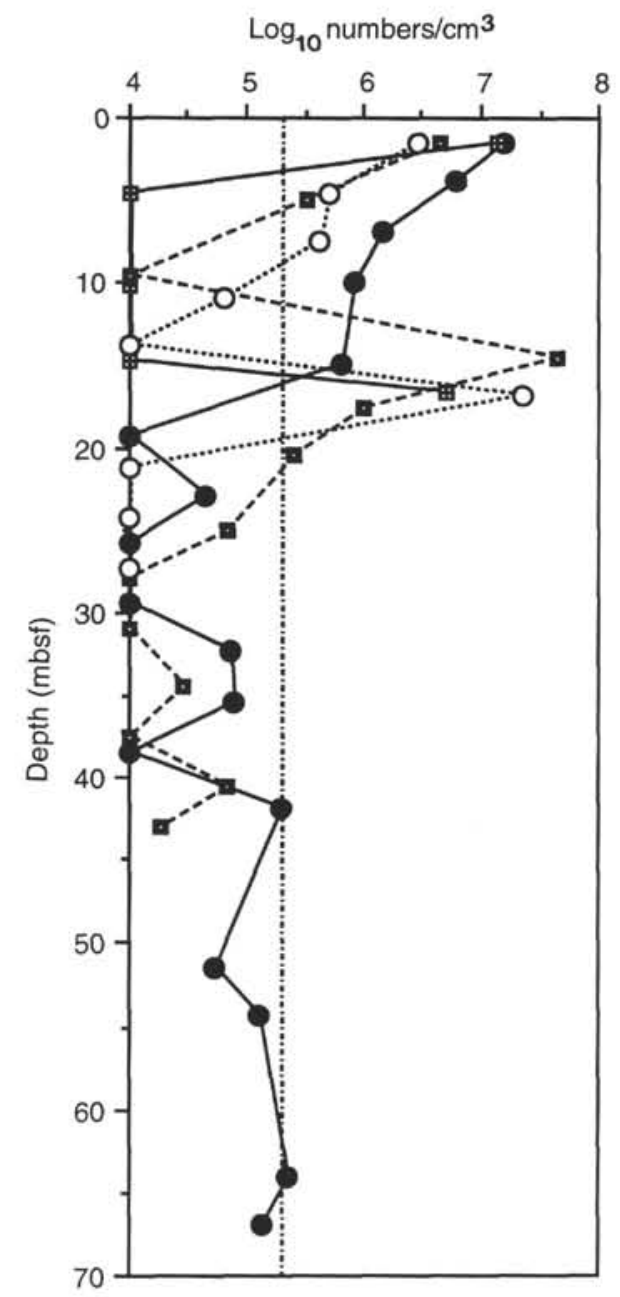

Figure 3. Depth distribution of total bacteria using the AODC technique from Holes $858 \mathrm{~A}$ (solid circles), 858B (open squares), 858C (solid squares), and 858D (open circles). Vertical dashed line at 5.29 represents the calculated "significance level" for the presence of bacterial cells.

samples had more than 5 cells/membrane filter these data are considered to have adequate reliability. A paired sample t-test between replicate total counts showed no significant difference $(t=2.04, N$ $=17, P>0.05$ ).

Unlike the data from Site 857 , these data cannot be combined. Bacterial distributions at the four holes differ significantly, not unexpectedly, as they were located along a transect into an active vent area, with thermal gradients increasing dramatically from $1.7^{\circ} \mathrm{C} / \mathrm{m}$ to $>11^{\circ} \mathrm{C} / \mathrm{m}$, compared to only $0.61^{\circ} \mathrm{C} / \mathrm{m}$ for Site 857 . Therefore, bacterial depth distributions, which are normally controlled by inputs to the sediment/water interface, particularly of organic carbon, are strongly influenced by temperature gradients and fluid flow, both vertical and lateral, which increase along the transect toward the active vents (Davis, Mottl, Fisher, et al., 1992). This complex situation requires careful analysis and in this context we view our interpretation as prefatory, particularly because only direct bacterial counts and a limited number of data points are available. Nevertheless, the data are clearly important, for although the microbiology of vent systems has been, and is being, actively studied (Baross and Deming, 1983; Trent et al., 1984; Baross and Deming, 1984; Jannasch and Mottl, 1985; Fiala and Stetter, 1986; Jannasch et al., 1988; Karl et al., 1988; Huber et al., 1989, 1990; Straube et al., 1990; Reysenbach and Deming, 1991; Stetter et al., in press), this is the first study to investigate deeper sediments in active vent areas.
As the presence of vent fluid flow is clearly reflected in increases in chlorinity at Holes 858A-858D (Davis, Mottl, Fisher, et al., 1992), bacterial distributions are plotted with chlorinity for each site (Fig. 4AD). Although Hole $858 \mathrm{~B}$ is nearest an active vent, being only a few meters away, Hole $858 \mathrm{D}$ had both higher temperatures at comparable depths $\left(197^{\circ} \mathrm{C}\right.$ at $19.5 \mathrm{mbsf}$ and $208^{\circ} \mathrm{C}$ at $18.5 \mathrm{mbsf}$, respectively) and higher chlorinities. The shallowest sediment samples were taken at $1.51 \mathrm{mbsf}$ in all four holes. The total counts at this depth were similar, ranging from $2.90 \times 10^{6}$ to $1.58 \times 10^{7}$ cells $/ \mathrm{cm}^{3}$ (Fig. 3). In all the holes these near-surface bacterial populations decreased markedly (percent of the $1.5 \mathrm{mbsf}$ total count remaining at $5 \mathrm{mbsf}$ is $21 \%, 7.5 \%, 0 \%$, and $13 \%$ for Holes $858 \mathrm{~A}, 858 \mathrm{C}, 858 \mathrm{~B}$, and $858 \mathrm{D}$, arranged in order by increasing temperature), whereas chlorinity initially increased. This rapid decrease in numbers is characteristic of near-surface bacterial populations (Novitsky and Karl, 1986; Cragg et al., 1990, 1992; Jørgensen et al., 1990; Parkes et al., 1990, in press) and reflects rapid utilization of the available organic matter, which quickly becomes limiting. This is consistent with a decrease in organic carbon at similar depth intervals in each hole, increases in alkalinity (Holes 858 A, 858C, and $858 \mathrm{D})$, and a decrease in pore water sulfate at Hole $858 \mathrm{D}(7.6$ $\mathrm{mmol} / \mathrm{kg}$ at $1.5 \mathrm{mbsf}$ to $0.4 \mathrm{mmol} / \mathrm{kg}$ at $5 \mathrm{mbsf}$ (Davis, Mottl, Fisher, et al., 1992). Therefore, although the total population is declining, it remains active; hence the presence of dividing cells (Fig. 5). At Hole $858 \mathrm{~A}$, which had the highest near-surface bacterial count, the rate of decrease in total bacteria becomes noticeably less steep after about $8 \mathrm{mbsf}$, a pattern frequently observed at this approximate depth (Cragg et al., 1992) and $18^{\circ} \mathrm{C}$ (Fig. 4A). But by $20 \mathrm{mbsf}$ and $35^{\circ} \mathrm{C}$, counts decrease rapidly and are below our "significance level." At deeper levels, the bacterial population appears to increase and possibly starts to adapt to the increasing temperature gradient but does not become significant. A similar pattern is shown by the dividing cells (Fig. 5).

The decrease in total bacteria at the hottest site, Hole 858D, is substantially different, because although bacterial populations are decreasing with depth in a pattern similar to that at Hole $858 \mathrm{~A}$, the temperature at about $8 \mathrm{mbsf}$ is higher $\left(76^{\circ} \mathrm{C}\right)$ (Fig. 4D). Bacterial populations then decrease rapidly and are below the "significance level" by approximately $90^{\circ} \mathrm{C}$, providing reasonable evidence that the bacterial populations at these two sites are optimized for different in-situ temperatures. Although the temperature where bacteria are decreasing rapidly at Hole $858 \mathrm{~A}\left(18^{\circ}-35^{\circ} \mathrm{C}\right)$ is not an extreme temperature for laboratory cultures, it is extreme for deep sediment bacteria, which exist where overlying water is usually between $1^{\circ}-4^{\circ} \mathrm{C}$ and the sediment thermal gradient is between $0.03^{\circ}$ and $0.1^{\circ} \mathrm{C} / \mathrm{m}$ (Legs 112,128 , 135). The higher temperature gradient probably limits the bacterial depth distribution to a much greater extent at this site compared with Site 857 , which has similar organic carbon (average over the top 5 mbsf is $0.48 \%$ at Site 858 and $0.56 \%$ at Site 857 ; Fig. 2), and other sites previously studied (Cragg et al., 1990, 1992). A similar situation exists at Hole $858 \mathrm{D}$, but the bacteria appear to be adapted to the elevated temperatures and are thus anaerobic thermophiles.

On the basis of temperature gradients and detailed geochemical and sedimentological data (Davis, Mottl, Fisher, et al., 1992) the four holes can be loosely grouped into "warm" (Holes 858A and $858 \mathrm{C}$ ) and "hot" (Holes 858B and 858D). The bacterial depth distributions show some important similarities within these groups (Fig. 6A-B). This is apparent for both the near-surface layers ( $0-10 \mathrm{mbsf})$ and the deeper levels of the warm sites (below about 20 mbsf, between $40^{\circ}-$ $120^{\circ} \mathrm{C}$, where bacterial populations are low [Fig. 6A]), and is consistent with the comparable thermal gradients (Holes 858A and 858C; $1.7^{\circ}$ and $3^{\circ} \mathrm{C} / \mathrm{m}$, respectively). Although the temperature gradient and increase in chlorinity reflect the impact of high-temperature fluids, this interaction, at these sites, is thought to be by thermal conductance and diffuse chemical reactions rather than direct fluid flow (Davis, Mottl, Fisher, et al., 1992), as is indicated by the steady increase in chlorinity at Hole 858A (Fig. 4A). The chlorinity pattern at Hole 858C (Fig. 4C), however, is different from that at Hole $858 \mathrm{~A}$, and decreases below about 20 mbsf. This indicates that some lateral fluid advection may 

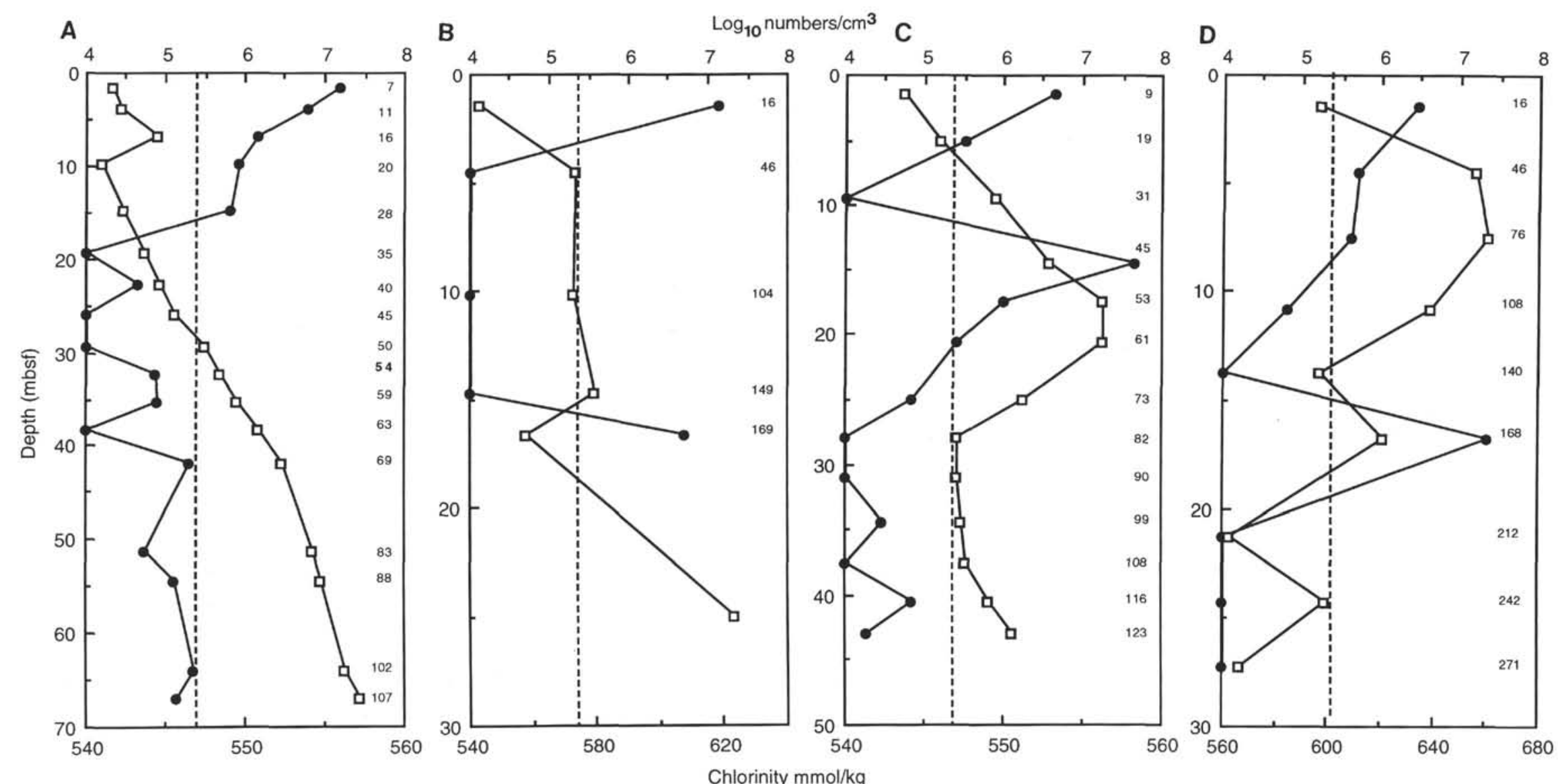

Figure 4. Depth distributions of total bacteria (solid circles) and chlorinities (open squares; Davis, Mottl, Fisher, et al, 1992) at Site 858. A. Hole 858A. B. Hole 858C C. Hole 858B. D. Hole 858D, Vertical dashed line at 5.29 represents the calculated "significance level" for the presence of bacterial cells. The column of numbers on the right of each graph are estimated in-situ temperatures interpolated from Davis, Mottl, Fisher, et al. (1992). 


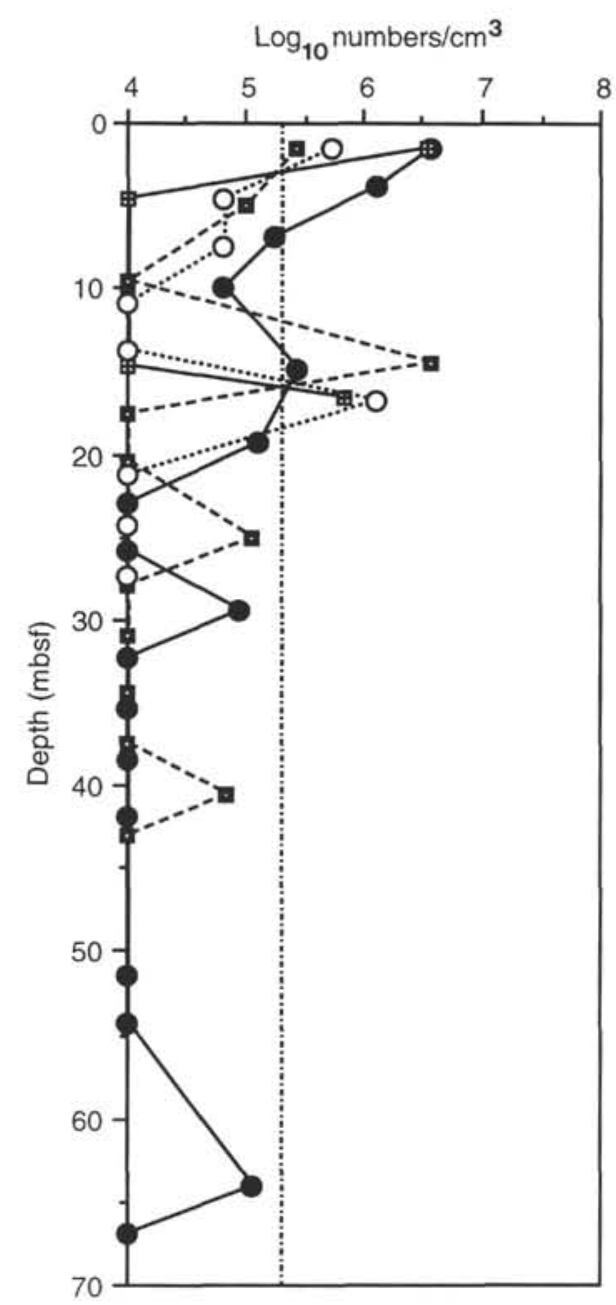

Figure 5. Depth distribution of numbers of dividing/divided bacterial cells from Holes 858A (solid circles), 858B (open squares), 858C (solid squares), and $858 \mathrm{D}$ (open circles). Vertical dashed line at 5.29 represents the calculated "significance level" for the presence of bacterial cells.

be occurring or may have occurred at shallow levels, about $30 \mathrm{mbsf}$ (Davis, Mottl, Fisher, et al., 1992). Whatever the cause of this decreased chlorinity, the bacterial population shows a significant $(P<$ 0.05 ) increase in numbers above the maximum in chlorinity and then follows subsequent changes in chlorinity (Fig. 4C). This peak and the sustained increase in the bacterial population occur within a temperature range of $45^{\circ}-80^{\circ} \mathrm{C}$, and hence the bacteria, at deeper levels at Hole $858 \mathrm{C}$, seem to be adapted to higher temperatures than the bacteria at Hole $858 \mathrm{~A}$. This conclusion is reasonable as Hole $858 \mathrm{C}$ is actually within the active vent field.

The two "hot" sites also have similar initial bacterial populations and increasing chlorinities (Figs. 4B and D), but the subsequent changes in bacterial populations differ (Fig. 6B). Both sites are influenced by near-surface lateral fluid flow from the active vent near Hole $858 \mathrm{~B}$; hence, their chlorinities are high. At Hole 858B, however, in contrast to Hole $858 \mathrm{D}$, both the chlorinity and bacterial counts stay relatively constant between about 5 and $15 \mathrm{mbsf}$ (Fig. 4B). This could be due initially to a layer high in inorganic carbon, which peaks at 5 mbsf and decreases to 13 mbsf, and an overlapping metalliferous sulfide layer between 10.4 and 12.7 mbsf. These layers may cap hydrothermal circulation in this zone (Davis, Mottl, Fisher, et al., 1992). This region would present a harsh environment for bacteria and thus would explain counts below the detection limit. Just beneath this barrier there is active vent fluid flow as reflected by the increase in chlorinity (Davis, Mottl, Fisher, et al., 1992) and temperature increases to about $169^{\circ} \mathrm{C}$. Remarkably, bacterial numbers increase significantly in Hole $858 \mathrm{~B}$ just above this zone; a similar increase occurs at Hole 858D (Hole 858B: $5.18 \times 10^{6} \mathrm{cells} / \mathrm{cm}^{3}$; Hole $858 \mathrm{D}$ : $2.27 \times 10^{7}$ cells $/ \mathrm{cm}^{3}$ ) only $60 \mathrm{~m}$ away (Fig. $6 \mathrm{~B}$ ), also associated with an increase in chlorinity (Fig. 4D) and a similar temperature, $168^{\circ} \mathrm{C}$. This was the lowermost sample from Hole 858B, but in Hole 858D chlorinity decreases again and bacterial numbers decrease below the detection limit at about $212^{\circ} \mathrm{C}$. The temperatures for these holes were interpolated from spot data obtained from the Water Sampling Temperature Probe (WSTP). Nevertheless the profiles are considered to be linear (Davis, Mottl, Fisher et al., 1992) and the bacterial counts at $168^{\circ} \mathrm{C}$ were made within 2.8 and $3.9 \mathrm{~m}$ of the spot measurements for Holes $858 \mathrm{~B}$ and $858 \mathrm{D}$, respectively.

It is difficult to attribute the presence of intact (Fig. 3) and dividing (Fig. 5) bacterial cells at these deeper layers and high temperatures to contamination from above during drilling, because at both "hot" sites, bacterial populations above are much lower; and in Hole 858B, populations are actually below detection limit for over $10 \mathrm{~m}$ (Fig. 4B). Another possible explanation could be the production of microspheres from solutions of protein and nucleic acids within hot sediments as they cool during recovery and sampling, having the appearance of cells (White, 1984), or the production of such microspheres under in-situ temperature and pressure conditions (Yanagawa and Kojima, 1985). It seems unlikely however, that this would also result in the increase in numbers of dividing cells (Fig. 5) and the rapid decrease in bacterial cells as temperatures increase further, deeper in the sediment (Fig. 4D). Hence the increase in bacterial populations in association with the increase in chlorinity at these "hot" sites indicates, as was the case in Hole $858 \mathrm{C}$, that the bacteria are introduced by, or respond to, influx of vent fluid. At present we cannot differentiate between these two alternatives. But even if the bacteria are being carried into the sediments by the vent fluid, the temperature of the supply water is likely to be similar or even higher than that of the sediment. This observation is consistent with earlier work of Baross et al., (1982, 1984), Baross and Deming (1985) and Deming and Baross (1986), which predicted the existence of hyperthermophilic microorganisms subsurface to active vents, as well as with the recent conclusions of Straube et al. (1990), based on particulate DNA analysis of hydrothermal fluid, that relatively intact bacteria do exist in the extremely hot fluids of some black smokers. Additionally Reysenbach and Deming (1991) have observed increasing barophily in hyperthermophiles isolated from the Juan de Fuca ridge and have postulated the existence of microorganisms deep in the subsurface of vent fields. The sediments studied here obviously warrant closer study as they potentially challenge, with respect to the temperature maximum for microbial existence, even the most thermophilic bacteria studied to date (Stetter et al., 1990, in press; Pledger and Baross, 1991).

\section{SUMMARY}

The presence and distribution of intact and dividing bacterial cells were determined in a transect into an active vent area at Site 858, and a reference site (Site 857 ) approximately $1.6 \mathrm{~km}$ away. Bacterial depth distributions at the reference site were similar to other sites previously studied, despite the relatively low organic carbon concentration $(0.56 \%)$, with populations decreasing from maximum numbers near surface to $107 \mathrm{mbsf}$, the deepest sample obtained. The overall depth profiles of both total bacteria and dividing cells were linear $\left(R^{2}=0.5\right)$, with scatter over the top $38 \mathrm{~m}$, where geochemical data indicated that bacterial organic carbon degradation was concentrated. Deviations from this linearity between 38 and 107 mbsf coincide with an interval of considerable chemical change, but may also be related to changes in the sedimentation rate.

In contrast, at the hydrothermal vent Site 858 , significant bacterial populations were limited to $64 \mathrm{mbsf}$, although near-surface popula- 

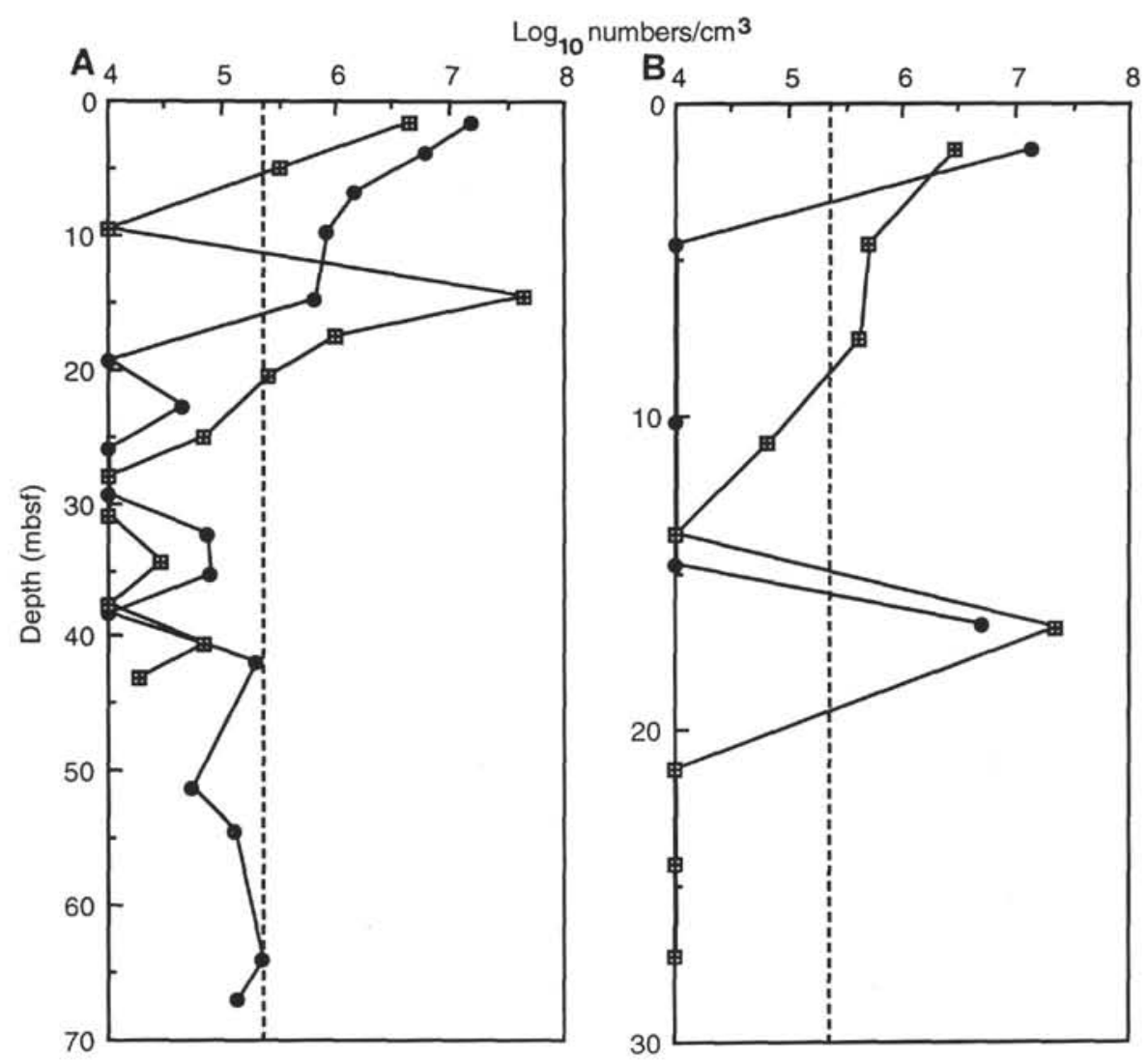

Figure 6. Depth distribution of total bacteria using the AODC technique. A. "Warm" Holes-Holes 858A (solid circles) and 858C (open squares). B. "Hot" holes-Holes 858B (solid circles) and 858D (open squares). Vertical dashed line at 5.29 represents the calculated "significance level" for the presence of bacterial/cells.

tions were similar to those at Site 857. Depth profiles of bacterial populations were related to chlorinity changes, which reflect the influence of vent fluid. At all sites the near-surface bacterial populations decreased rapidly with depth, related to an increasing temperature gradient across the transect into the vent field from $35^{\circ}$ to $76^{\circ} \mathrm{C}$. This reflects adaptation of the in-situ population to the increasing thermal gradient. The higher temperature gradient probably limits the bacterial depth distribution at these vent sites to a much greater extent than at Site 857 , which has a similar organic carbon content. The two "hot" holes, $858 \mathrm{~B}$ and $858 \mathrm{D}$, were influenced by near-surface lateral fluid flow; at both these sites there was a significant subsurface peak in the bacterial population associated with increases in chlorinity and a temperature increase to $169^{\circ} \mathrm{C}$. The presence of these bacterial populations is difficult to attribute to contamination during drilling from above, and thus may represent uniquely high-temperature adapted bacteria.

\section{ACKNOWLEDGMENTS}

This work was funded while B.A. Cragg was in receipt of a Special Topics Research Fellowship (GST/F90/2) provided by the Natural Environment Research Council, United Kingdom. We thank Rowena Duckworth who collected the samples on board ship and Drs. Jon Getliff and Simon Bale for constructive comments on a draft manuscript. We acknowledge the support and facilities provided by Bristol University, and we are grateful to the Ocean Drilling Program for supplying samples from Leg 139.

\section{REFERENCES}

Baross, J.A., and Deming, J.D., 1983. Growth of "black smoker" bacteria at temperatures of at least $250^{\circ} \mathrm{C}$. Nature, 303:423-426.

, 1984. Reply from John A. Baross and Jody W. Deming. Nature, $307: 740$.

, 1985. The role of bacteria in the ecology of black smoker environments. In Jones, M.L. (Ed.), The Hydrothermal Vents of the Eastern Pacific-an Overview. Biol. Soc. Wash. Bull., 6:355-371.

Baross, J.A., Lilley, M.D., and Gordon, L.I., 1982. Is the $\mathrm{CH}_{4}, \mathrm{H}_{2}$ and $\mathrm{CO}$ venting from submarine hydrothermal systems produced by thermophilic bacteria? Nature, 298:366-368.

Baross, J.A., Deming, J.W., and Becker, R.R., 1984. Evidence for growth of bacteria at high temperature and pressure. Proc. 3rd Int. Symp. Microbial Ecol., East Lansing, MI.

Cragg, B.A., in press. Bacterial profiles in deep sediment layers from the Lau Basin, Site 834. In Parson, L., Hawkins, J., Allan, J., et al., Proc. ODP, Sci. Results, 135: College Station, TX (Ocean Drilling Program).

Cragg, B.A., Parkes, R.J., Fry, J.C., Herbert, R.A., Wimpenny, J.W.T., and Getliff, J.M., 1990. Bacterial biomass and activity profiles within deep sediment layers. In Suess, E., von Huene, R., et al., Proc. ODP, Sci. Results, 112: College Station, TX (Ocean Drilling Program), 607-619.

Abbreviations for names of organizations and publications in ODP reference lists follow the style given in Chemical Abstracts Service Source Index (published by American Chemical Society). 
Cragg, B.A., Harvey, S.M., Fry, J.C., Herbert, R.A., and Parkes, R.J., 1992. Bacterial biomass and activity in the deep sediment layers of the Japan Sea, Hole 798B - ODP Leg 128. In Pisciotto, K., Ingle, J.C., Jr., von Breymann, M.J., Barron, J., et al., Proc. ODP, Sci. Results, 127/128: College Station, TX (Ocean Drilling Program), 761-775.

Davis, E.E., Mottl, M.J., Fisher, A.T., et al., 1992. Proc. ODP, Init. Repts., 139: College Station, TX (Ocean Drilling Program).

Deming, J.W., and Baross, J.A., 1986. Solid medium for culturing black smoker bacteria at temperatures to $120^{\circ} \mathrm{C}$. Appl. Environ. Microbiol., 51:238-243.

Fiala, G., and Stetter, K.O., 1986. Pyrococcus furiosus sp. nov. represents a novel genus of marine heterotrophic archaebacteria growing optimally at $100^{\circ} \mathrm{C}$. Arch. Mikrobiol., 145:56-61.

Fry, J.C., 1988. Determination of biomass. In Austin, B. (Ed.), Methods in Aquatic Bacteriology: Chichester (Wiley), 27-72.

Goulder, R., 1977. Attached and free bacteria in an estuary with abundant suspended solids. J. Appl. Bacteriol., 43:399-405.

Huber, R., Kurr, M., Jannasch, H.W., and Stetter, K.O., 1989. A novel group of abyssal methanogenic archaebacteria (Methanopyrus) growing at $110^{\circ} \mathrm{C}$. Nature, $342: 833-834$.

Huber, R., Stoffers, P., Cheminee, J.L., Richnow, H.H., and Stetter, K.O., 1990. Hyperthermophilic archaebacteria within the crater and open-sea plume of erupting Macdonald Seamount. Nature, 345:179-182.

Jannasch, H.W., and Mottl, M.J., 1985 Geomicrobiology of deep-sea hydrothermal vents. Science, 229:717-725.

Jannasch, H.W., Wirsen, C.O., Molyneaux, S.J., and Langworthy, T.A., 1988. Extremely thermophilic fermentative archaebacteria of the genus Desulfurococcus from deep-sea hydrothermal vents. Appl. Environ. Microbiol., 54:1203-1209.

Jørgensen, B.B., Bang, M., Blackburn, T.H., 1990. Anaerobic mineralization in marine sediments from the Baltic Sea-North Sea transition. Mar. Ecol. Prog. Ser., 59:39-54.

Karl, D.M., Taylor, G.T., Novitsky, J.A., Jannasch, H.W., Wirsen, C.O., Pace, N.P., Lane, D.J., Olsen, G.J., and Giovannoni, S.J., 1988. A microbiological study of Guaymas Basin high temperature hydrothermal vents. DeepSea Res. Part A, 35:777-791.

Kirchman, D., Sigda, J., Kapuscinski, R., and Mitchell, R., 1982. Statistical analysis of the direct count method for enumerating bacteria. Appl. Environ. Microbiol., 44:376-382.
Novitsky, J.A., and Karl, D.M., 1986. Characterization of microbial activity in the surface layers of a coastal sub-tropical sediment. Mar. Ecol. Prog. Ser., 28:49-55.

Parkes, R.J., Cragg, B.A., Fry, J.C., Herbert, R.A., and Wimpenny, J.W.T., 1990. Bacterial biomass and activity in deep sediment layers from the Peru margin. Philos. Trans. R. Soc. London A, 331:139-153.

Parkes, R.J., Cragg, B.A., Getliff, J.M., and Fry J.C., in press. Presence and activity of bacteria in deep sediments from marine environments. Abstr. Sixth Int. Symp. Microbial Ecology, Barcelona, Spain.

Pledger, R.J., and Baross, J.A., 1989. Characterization of an extremely thermophilic Archaebacterium isolated from a black smoker polychaete (Paralvinella sp.) at the Juan de Fuca Ridge. System. Appl. Microbiol., 12:249-256.

Pledger, R.J., and Baross, J.A., 1991. Preliminary description and nutritional characterization of a chemoorganotrophic archaeobacterium growing at temperatures of up to $110^{\circ} \mathrm{C}$ isolated from a submarine hydrothermal vent environment. J. Gen. Microbiol., 137:203-211.

Reysenbach, A.-L. and Deming, J.W., 1991. Effects of hydrostatic pressure on growth of hyperthermophilic archaebacteria from the Juan de Fuca ridge. Appl. Environ. Microbiol., 57:1271-1274.

Stetter, K.O., Fiala, G., Huber, G., Huber, R., and Segerer, A., 1990. Hyperthermophilic microorganisms. FEMS Microbiol. Rev., 75:117-124.

Stetter, K.O., Hoffmann, A., and Huber, R., in press. Microorganisms adapted to high temperature environments. Abstr. Sixth Int. Symp. Microbial Ecology, Barcelona, Spain.

Straube, W.L., Deming, J.W., Somerville, C.C., Colwell, R.R., and Baross, J.A., 1990. Particulate DNA in smoker fluids: evidence for existence of microbial populations in hot hydrothermal systems Appl. Environ. Microbiol., 56:1440-1447.

Trent, J.D., Chastain, R.A., and Yayanos, A.A., 1984. Possible artefactual basis of apparent bacterial growth at $250^{\circ} \mathrm{C}$. Nature, $307: 737-740$.

White, R.H., 1984. Hydrolytic stability of biomolecules at high temperatures and its implication for life at $250^{\circ} \mathrm{C}$. Nature, $310: 430-432$.

Yanagawa, H., and Kojima, K., 1985. Thermophilic microspheres of peptidelike polymers and silicates formed at $250^{\circ} \mathrm{C}$. J. Biochem., 97:1521-1524.

Date of initial receipt: 20 January 1993

Date of acceptance: 2 July 1993

Ms 139SR-236 